\title{
Crude Oil in Water Drilling Fluid Properties and Application in Horizontal Wellbore Drilling
}

\author{
Liye Bai $^{1}$ \\ ${ }^{1}$ Drilling Technology Research Institute, Shengli Petroleum Engineering Co., Ltd, SINOPEC, $827^{\#}$ \\ Beiyi Road, Dongying City, Shandong Province, China
}

390596508@qq.com

Keywords: Crude oil in Water drilling fluid; Emulsifier; Lubrication; Application

\begin{abstract}
Oil in water drilling fluid is a suitable water based drilling fluid for horizontal well, because of good lubricity, liquidity and borehole stability. Optimized and matching emulsifiers, in the2:8 ratio of oil to water, the emulsifiers OP-10+SP-80 ratio of 3:2 is the best effect of emulsion stability, the formation of oil in water drilling fluid system have low filter loss, strong stability, low lubricating coefficient properties, which can meet the needs of drilling horizontal well design. The crude oil in Water drilling fluid application in Xin Sha21-1H,Xin Sha23-1H and XinSha 21-3H well shows that, the oil in water drilling fluid system has good rheological properties and lubricating property. The average single well diameter expanding rate of $12.23 \%$, lower than $16.75 \%$ with other well. Utilization drilling rate increased from $35.82 \%$ to $54.67 \%$, which increase $52.6 \%$ significantly reduced the horizontal well drilling cycle.
\end{abstract}

\section{Introduction}

The development of horizontal drilling technology provide a new way for improve exploration, the technology has become the one of most important oil industry technology in now ${ }^{[1]}$. The current level of foreign drilling fluid system is mainly used in the drilling process are five: polymer drilling fluid, oil-based drilling fluid, clean brine drilling fluid, mixed metal layered hydroxides and foam or inflatable drilling fluid ${ }^{[2 \sim 3]}$.

Oil in water drilling fluid system has both water-based drilling fluid characteristics and has oil-based drilling fluid lubrication advantages, mainly used to solve some of the horizontal well borehole instability, poor performance of the drilling fluid lubrication technical problems. This system performance is stability, has good liquidity, low fluid filter loss, wellbore stability strong capacity; performance easily monitor, control and adjustment. The system has low cost compared to pure oil-based drilling fluid, low environmental pollution, is one of the preferred chose for horizontal well drilling.

\section{The establishing of oil in water drilling fluid emulsifier}

According to theory, the HLB value (hydrophilic-lipophilic balance) in the range of 8-18, emulsifier can be used as emulsifier in oil in water drilling fluid. But in the actual application process, one emulsifier emulsifying effect is not ideal, usually several mutually emulsifier mixed use. Emulsifiers having an HLB value plus the corresponding proportion and nature. From raw material economy and practical point of view, the project choose crude oil as based oil, $\mathrm{pH}$ is adjusted to 10, evaluate the stability of the emulsion, optimization preferably suitable emulsifier. In this study, referring to the drilling fluid emulsion stability evaluation in "SY-T 6615-2005 drilling fluid emulsifier evaluation process", doing the evaluation about the commonly used emulsifier for emulsification. The evaluation show in table 1. 
Table1 2:8 Oil-water emulsion stability

\begin{tabular}{|c|c|c|c|c|}
\hline \multirow{2}{*}{ No. } & \multirow{2}{*}{ Emulsifier name } & \multicolumn{3}{|c|}{ Stratification after 24h } \\
\cline { 3 - 5 } & & Upper layer & Middle layer & Low layer \\
\hline 1 & TW-85 & $34 \mathrm{~mL}$ & \multicolumn{2}{|c|}{ No stratification } \\
\hline 2 & OP-10 & $34 \mathrm{~mL}$ & \multicolumn{2}{|c|}{ No stratification } \\
\hline 3 & TW-80 & $38 \mathrm{~mL}$ & \multicolumn{2}{|c|}{ No stratification } \\
\hline 4 & ABS & $14 \mathrm{~mL}$ & \multicolumn{2}{|c|}{ No stratification } \\
\hline 5 & TW-80:OP-10=1:1 & $21 \mathrm{~mL}$ & $8 \mathrm{~mL}$ & Clear \\
\hline 6 & TW-80:OP-10=2:1 & $19 \mathrm{~mL}$ & $12 \mathrm{~mL}$ & Clear \\
\hline 7 & TW-80:OP-10=3:2 & $18 \mathrm{~mL}$ & $10 \mathrm{~mL}$ & Clear \\
\hline 8 & TW-80:SP-80=1:1 & $5 \mathrm{~mL}$ & $9 \mathrm{~mL}$ & Clear \\
\hline 9 & TW-80:SP-80=2:1 & $6 \mathrm{~mL}$ & $12 \mathrm{~mL}$ & Clear \\
\hline 10 & TW-80:SP-80=3:2 & $4 \mathrm{~mL}$ & $8 \mathrm{~mL}$ & Clear \\
\hline 11 & TW-85:SP-80=1:1 & $15 \mathrm{~mL}$ & $18 \mathrm{~mL}$ & Clear \\
\hline 12 & TW-85:SP-80=2:1 & $17 \mathrm{~mL}$ & $17 \mathrm{~mL}$ & Clear \\
\hline 13 & TW-85:SP-80=3:2 & $14 \mathrm{~mL}$ & $16 \mathrm{~mL}$ & Clear \\
\hline 14 & OP-10:SP-80=1:1 & $4 \mathrm{~mL}$ & $12 \mathrm{~mL}$ & Clear \\
\hline 15 & OP-10:SP-80=2:1 & $3 \mathrm{~mL}$ & $14 \mathrm{~mL}$ & Clear \\
\hline 16 & OP-10:SP-80=3:2 & $2 \mathrm{~mL}$ & $9 \mathrm{~mL}$ & Clear \\
\hline 17 & ABS: SP-80=1:1 & $14 \mathrm{~mL}$ & $17 \mathrm{~mL}$ & Transparent \\
\hline 18 & ABS: SP-80=2:1 & $15 \mathrm{~mL}$ & $19 \mathrm{~mL}$ & Transparent \\
\hline 19 & ABS: SP-80=3:2 & $13 \mathrm{~mL}$ & $22 \mathrm{~mL}$ & Transparent \\
\hline
\end{tabular}

Remark: The upper layer is not emulsified crude oil, the middle layer is breaking emulsions, the low layer is stable emulsions.

From the experimental date in Table 1, in the oil-water ration 2:8 cases, crude oil can't be emulsified by a single emulsifier, and can't form a stable oil-in-water emulsion system. The use of complex ways to emulsify the crude oil has more significant effect, In order to research the effect of the amount of emulsifier on the emulsion stability.Emulsifier dosage evaluate experimental data are shown in Table 2.

Table 2 Emulsifier dosage evaluation of experimental data

\begin{tabular}{|c|c|c|c|c|c|}
\hline \multirow{2}{*}{ No } & \multirow{2}{*}{ Emulsifier name } & \multirow{2}{*}{ Ratio } & \multicolumn{3}{|c|}{ Stratification after 24h } \\
\hline & & & Upper layer & Middle layer & Low layer \\
\hline 1 & \multirow{5}{*}{ TW-80:SP-80=3:2 } & $4 \%$ & $15 \mathrm{~mL}$ & $6 \mathrm{~mL}$ & Clear \\
\hline 2 & & $6 \%$ & $7 \mathrm{~mL}$ & $12 \mathrm{~mL}$ & Clear \\
\hline 3 & & $10 \%$ & $4 \mathrm{~mL}$ & $8 \mathrm{~mL}$ & Clear \\
\hline 4 & & $15 \%$ & $5 \mathrm{~mL}$ & $9 \mathrm{~mL}$ & Clear \\
\hline 5 & & $20 \%$ & $3 \mathrm{~mL}$ & $9 \mathrm{~mL}$ & Clear \\
\hline 6 & \multirow{5}{*}{ OP-10:SP-80=3:2 } & $4 \%$ & $14 \mathrm{~mL}$ & $16 \mathrm{~mL}$ & Clear \\
\hline 7 & & $6 \%$ & $11 \mathrm{~mL}$ & $7 \mathrm{~mL}$ & Clear \\
\hline 8 & & $10 \%$ & $2 \mathrm{~mL}$ & $9 \mathrm{~mL}$ & Clear \\
\hline 9 & & $15 \%$ & $2.5 \mathrm{~mL}$ & $10 \mathrm{~mL}$ & Clear \\
\hline 10 & & $20 \%$ & $2 \mathrm{~mL}$ & $8 \mathrm{~mL}$ & Clear \\
\hline
\end{tabular}

Remark: The upper layer is not emulsified crude oil, the middle layer is breaking emulsions, the low layer is stable emulsions.

From the experimental date in Table 2, in the oil-water ration 2:8 cases, the choice of emulsifier dosage is $10 \%$ of crude oil, it has been able to promote sufficiently emulsified crude oil, has good emulsion stability.

\section{Oil-in-water drilling fluid system optimization}

On the basis of the water-based drilling fluid formulations research emulsifier system OP-10: SP-80 = 3: 2 is introduced into the drilling fluid performance changes, investigate different oil-in-water drilling fluid rheology and lubricity. Show in Table 3. 
Table 3 The influence of oil-water ratio to drilling fluid

\begin{tabular}{|c|c|c|c|c|c|c|c|c|c|c|}
\hline $\begin{array}{c}\text { Oil-water } \\
\text { ratio }\end{array}$ & $\begin{array}{c}\rho \\
\mathrm{g} / \mathrm{cm}^{3}\end{array}$ & $\begin{array}{c}\mathrm{FV} \\
\mathrm{S}\end{array}$ & $\begin{array}{c}\mathrm{PV} \\
\mathrm{mPa} \cdot \mathrm{s}\end{array}$ & $\begin{array}{c}\mathrm{YP} \\
\mathrm{Pa}\end{array}$ & $\begin{array}{c}\mathrm{G}_{1} / \mathrm{G}_{2} \\
\mathrm{~Pa}\end{array}$ & $\begin{array}{c}\mathrm{FL} \\
\mathrm{mL}\end{array}$ & $\mathrm{K}_{\mathrm{f}}$ & $\mathrm{EP}$ & $\begin{array}{c}\text { viscosity } \\
\text { coefficient }\end{array}$ & Remark \\
\hline \multirow{2}{*}{$1: 9$} & 1.60 & 59 & 23 & 15 & $5 / 18$ & 2.3 & $/$ & $/$ & $/$ & $\begin{array}{c}\text { Room } \\
\text { temperature }\end{array}$ \\
\cline { 2 - 11 } & 1.60 & 48 & 24 & 4.5 & $1.5 / 6$ & 1.8 & 0.1183 & 0.2169 & 0.0542 & After aging \\
\hline \multirow{2}{*}{$2: 8$} & 1.60 & 49 & 21 & 13 & $6.5 / 20$ & 1.8 & $/$ & $/$ & $/$ & $\begin{array}{c}\text { Room } \\
\text { temperature }\end{array}$ \\
\cline { 2 - 11 } $3: 7$ & 1.60 & 41 & 22 & 5.5 & $1.5 / 8$ & 1.2 & 0.0930 & 0.1885 & 0.0262 & After aging \\
\hline \multirow{2}{*}{3} & 1.60 & 73 & 38 & 18 & $9 / 23$ & 1.3 & $/$ & $/$ & $/$ & $\begin{array}{c}\text { Room } \\
\text { temperature }\end{array}$ \\
\cline { 2 - 10 } & 1.60 & 65 & 40 & 12 & $5 / 21$ & 0.8 & 0.0835 & 0.1778 & 0.0262 & After aging \\
\hline
\end{tabular}

From the experimental date in Table 3, using oil-water ratio 2: 8, $\mathrm{Kf}$ value is less than 0.1, can reach horizontal wells lubrication requirements, while medium pressure filter loss is also less than $1.5 \mathrm{~mL}$, thereby facilitating horizontal wells wall stability.

According to the basic composition of the oil-in-water drilling fluid system, Specific formula is as follows: $3 \sim 4 \% \mathrm{NV}-1+0.5 \% \sim 1 \% \mathrm{OP}-10+13 \% \sim 17 \%$ Crude oil $\quad+0.3 \% \sim 0.8 \% \mathrm{SP}-80$ $+0.05 \% \sim 0.1 \% \mathrm{NaOH}+2 \sim 4 \% \mathrm{SMP}-1+2 \sim 4 \% \mathrm{SMC}+0.2 \% \sim 0.8 \% \mathrm{CaO}+1 \% \sim 3 \%$ anti-sloughing agent $(\mathrm{FGH})+\mathrm{BaSO} 4$.

To evaluate the high temperature stability of the oil-in-water drilling fluid system, the preparation of a density of $1.60 \mathrm{~g} / \mathrm{cm}^{3}$ oil-in-water drilling fluid temperature is $80^{\circ} \mathrm{C}, 90^{\circ} \mathrm{C}, 100^{\circ} \mathrm{C}$ temperature stability experimental. Show in Table 4.

Table 4 High temperature stability test data

\begin{tabular}{|c|c|c|c|c|c|c|c|c|}
\hline Aging & $\mathrm{FV}$ & $\mathrm{PV}$ & $\mathrm{YP}$ & $\mathrm{G}_{1} / \mathrm{G}_{2}$ & $\mathrm{FL}$ & \multicolumn{2}{|c|}{$\mathrm{HTHP} / 100^{\circ} \mathrm{C}$} & \multirow{2}{*}{ Remark } \\
\cline { 1 - 4 } $\mathrm{condition}$ & $\mathrm{s}$ & $\mathrm{mPa} . \mathrm{s}$ & $\mathrm{Pa}$ & $\mathrm{Pa}$ & $\mathrm{mL}$ & $\mathrm{FL} / \mathrm{mL}$ & $\mathrm{K} / \mathrm{mm}$ & \\
\hline $80^{\circ} \mathrm{C} \times 16 \mathrm{~h}$ & 41 & 22 & 5.5 & $1.5 / 8$ & 1.2 & 4.8 & 0.6 & $\begin{array}{c}\text { No demulsification } \\
\text { stratification }\end{array}$ \\
\hline $90^{\circ} \mathrm{C} \times 16 \mathrm{~h}$ & 43 & 25 & 5 & $4 / 9.5$ & 1.8 & 6.2 & 0.8 & $\begin{array}{c}\text { No demulsification } \\
\text { stratification }\end{array}$ \\
\hline $90^{\circ} \mathrm{C} \times 32 \mathrm{~h}$ & 39 & 20 & 4.5 & $3 / 7.5$ & 2.6 & 7.2 & 0.6 & $\begin{array}{c}\text { Trace demulsification } \\
\text { stratification }\end{array}$ \\
\hline $100^{\circ} \mathrm{C} \times 16 \mathrm{~h}$ & 40 & 25 & 5.5 & $5.5 / 15.5$ & 2.8 & 6.4 & 0.7 & $\begin{array}{c}\text { Trace demulsification } \\
\text { stratification }\end{array}$ \\
\hline
\end{tabular}

From the experimental date in Table 4, oil-in-water drilling fluid system temperature resistance up to $100^{\circ} \mathrm{C}$, the actual operation of the site may need to appropriate adjustments.

\section{Application of oil-in-water drilling fluid in horizontal wells}

Oil-in-water drilling fluid test wells drilled a total of three horizontal wells, respectively Xinsha 21-1H, Xinsha 23-1H and Xinsha 21-3H well, which aims layer are Shaximiao, The test results are shown in Table 5.

Table 5 Test well and no test well basic fact sheet

\begin{tabular}{|c|c|c|c|c|c|c|}
\hline No & Well No. & Well type & Drilling & Drilled & The maximum & Remark \\
\hline 1 & Xinsha21-1H & Horizontal well & Oil-in-wate & J2s & $93.43^{\circ} / 2551.86 \mathrm{~m}$ & Test well \\
\hline 2 & Xinsha23-1H & Horizontal well & Oil-in-wate & $\mathrm{J} 2 \mathrm{~s}$ & $92.4^{\circ} / 2697.05 \mathrm{~m}$ & Test well \\
\hline 3 & Xinsha21-3H & Horizontal well & Oil-in-wate & $\mathrm{J} 2 \mathrm{~s}$ & $92.53^{\circ} / 2421.51 \mathrm{~m}$ & Test well \\
\hline
\end{tabular}

Three wells in the deflecting and horizontal section adding 5\% to $10 \%$ of crude oil, while adding emulsifier (SP-80, OP-10) to meet the requirements of drilling fluid lubricating properties, and according to the drilling speed, speed replenish footage various processing agents to keep its content in drilling fluid. Kf value is maintained at $<0.12$, dynamic plastic ratio controlled in 0.4 to 0.6, the performance of the oil-in-water drilling fluid as shown in Tables6 to 8. 
Table 6 The performance of oil-in-water drilling fluid in Xinsha21-1H

\begin{tabular}{|c|c|c|c|c|c|c|c|c|c|c|c|c|}
\hline $\begin{array}{c}\text { Well } \\
\text { depth } \\
\mathrm{m}\end{array}$ & $\begin{array}{c}\rho \\
\mathrm{g} / \mathrm{cm} 3\end{array}$ & $\begin{array}{c}\mathrm{FV} \\
\mathrm{s}\end{array}$ & $\begin{array}{c}\mathrm{FL} \\
\mathrm{ml}\end{array}$ & $\begin{array}{c}\mathrm{K} \\
\mathrm{mm}\end{array}$ & $\mathrm{pH}$ & $\begin{array}{c}\mathrm{YP} \\
\mathrm{Pa}\end{array}$ & $\begin{array}{c}\mathrm{PV} \\
\mathrm{mPa} . \mathrm{s}\end{array}$ & $\begin{array}{c}\mathrm{G} 1 / \mathrm{G} 2 \\
\mathrm{~Pa}\end{array}$ & $\begin{array}{c}\mathrm{Cs} \\
\%\end{array}$ & $\begin{array}{c}\text { Vs } \\
\%\end{array}$ & $\begin{array}{c}\text { Oil } \\
\text { content\% }\end{array}$ & Kf \\
\hline 2400 & 2.01 & 56 & 3 & 0.5 & 9 & 13 & 27 & $7 / 16$ & 0.2 & 31 & 8 & 0.109 \\
\hline 2450 & 1.98 & 44 & 3.6 & 0.5 & 9 & 12 & 24 & $5 / 13$ & 0.2 & 32 & 8 & 0.108 \\
\hline 2920 & 1.93 & 47 & 3.0 & 0.5 & 9 & 11.5 & 23 & $6.5 / 15$ & 0.2 & 30 & 8 & 0.109 \\
\hline
\end{tabular}

Table 7 The performance of oil-in-water drilling fluid in Xinsha23-1H

\begin{tabular}{|c|c|c|c|c|c|c|c|c|c|c|c|c|}
\hline $\begin{array}{c}\text { Well depth } \\
\mathrm{m}\end{array}$ & $\begin{array}{c}\rho \\
\mathrm{g} / \mathrm{cm} 3\end{array}$ & $\begin{array}{c}\mathrm{FV} \\
\mathrm{s}\end{array}$ & $\begin{array}{c}\mathrm{FL} \\
\mathrm{ml}\end{array}$ & $\begin{array}{c}\mathrm{K} \\
\mathrm{mm}\end{array}$ & $\mathrm{pH}$ & $\begin{array}{c}\text { YP } \\
\mathrm{Pa}\end{array}$ & $\begin{array}{c}\mathrm{PV} \\
\mathrm{mPa} . \mathrm{s}\end{array}$ & $\begin{array}{c}\mathrm{G} 1 / \mathrm{G} 2 \\
\mathrm{~Pa}\end{array}$ & $\begin{array}{c}\mathrm{Cs} \\
\%\end{array}$ & $\begin{array}{c}\text { Vs } \\
\%\end{array}$ & $\begin{array}{c}\text { Oil } \\
\text { content } \\
\%\end{array}$ & Kf \\
\hline 2600 & 1.84 & 42 & 2.8 & 0.5 & 9 & 11 & 25 & $6 / 13$ & 0.2 & 30 & 6 & 0.1001 \\
\hline 2700 & 1.81 & 40 & 2.8 & 0.5 & 10 & 10.5 & 25 & $6 / 13.5$ & 0.2 & 30 & 7 & 0.098 \\
\hline 3240 & 1.89 & 44 & 2.6 & 0.5 & 9 & 11.5 & 24 & $6 / 14$ & 0.2 & 30 & 8 & 0.083 \\
\hline
\end{tabular}

Table 8 The performance of oil-in-water drilling fluid in Xinsha23-1H

\begin{tabular}{|c|c|c|c|c|c|c|c|c|c|c|c|c|}
\hline $\begin{array}{c}\text { Well depth } \\
\mathrm{m}\end{array}$ & $\begin{array}{c}\rho \\
\mathrm{g} / \mathrm{cm} 3\end{array}$ & $\begin{array}{c}\mathrm{FV} \\
\mathrm{s}\end{array}$ & $\begin{array}{c}\mathrm{FL} \\
\mathrm{ml}\end{array}$ & $\begin{array}{c}\mathrm{K} \\
\mathrm{mm}\end{array}$ & $\mathrm{pH}$ & $\begin{array}{c}\mathrm{YP} \\
\mathrm{Pa}\end{array}$ & $\begin{array}{c}\mathrm{PV} \\
\mathrm{mPa} . \mathrm{s}\end{array}$ & $\begin{array}{c}\mathrm{G} 1 / \mathrm{G} 2 \\
\mathrm{~Pa}\end{array}$ & $\begin{array}{c}\mathrm{Cs} \\
\%\end{array}$ & $\begin{array}{c}\text { Vs } \\
\%\end{array}$ & $\begin{array}{c}\text { Oil } \\
\text { content } \\
\%\end{array}$ & Kf \\
\hline 2008 & 1.89 & 40 & 3.8 & 0.5 & 9 & 10 & 23 & $5.5 / 13.5$ & 0.2 & 31 & 5 & 0.1267 \\
\hline 2433 & 1.90 & 41 & 3.0 & 0.5 & 9 & 15 & 23 & $11 / 16.5$ & 0.2 & & 9 & 0.1183 \\
\hline 2722 & 1.90 & 42 & 2.6 & 0.5 & 9 & 14.5 & 25 & $8.5 / 18$ & 0.2 & 33 & & 0.1183 \\
\hline 2942 & 1.93 & 42 & 2.4 & 0.5 & 9 & 14.5 & 26 & $9 / 18$ & 0.2 & 34 & 10 & 0.1183 \\
\hline
\end{tabular}

Since western Sichuan middle and low layer horizontal wells drilled in the multi-layer bit prone to collapse, and contains a large section of soft shale drilling test easily swelling necking or off the block, to the anti-drilling collapse has brought great difficulties, oil in water drilling fluid and zwitterionic polysulfonate drilling fluid in three wells enlargement rate with conventional comparison shown in Table 9.

Table 9 Table of test wells and non-test wells well bore stabilizing effect

\begin{tabular}{|c|c|c|c|c|c|}
\hline No & Well number & Drilling fluid & $\begin{array}{c}\text { Kickoff point } \\
\mathrm{m}\end{array}$ & $\begin{array}{c}\text { well diameter } \\
\text { enlargement ratio } \\
\%\end{array}$ & Remark \\
\hline 1 & Xinsha 2H & $\begin{array}{c}\text { Zwitterionic } \\
\text { polysulfonate } \\
\text { drilling fluid }\end{array}$ & 2163 & 14.82 & Non-test well \\
\hline 2 & Xinsha311H & $\begin{array}{c}\text { Zwitterionic } \\
\text { polysulfonate } \\
\text { drilling fluid }\end{array}$ & 1951 & 14.55 & Non-test well \\
\hline 3 & Xinsha 21-1H & $\begin{array}{c}\text { Oil-in-water } \\
\text { drilling fluid }\end{array}$ & 1810 & 14.50 & Test well \\
\hline 4 & Xinsha 23-1H & $\begin{array}{c}\text { Oil-in-water } \\
\text { drilling fluid }\end{array}$ & 1980 & 11.10 & Test well \\
\hline 5 & Xinsha 21-3H & $\begin{array}{c}\text { Oil-in-water } \\
\text { drilling fluid }\end{array}$ & 1730 & 11.09 & Test well \\
\hline
\end{tabular}

Remark: The range of well diameter enlargement ratio is $100 \mathrm{~m}$ range of kickoff point.

From the date in Table 9, before the apply of new drilling fluid system and borehole stability technology, the average single well hole enlargement ratio was $14.69 \%$. After using the oil-in-water drilling fluid system average single well hole enlargement ratio was $12.23 \%$, representing a decrease of $16.75 \%$, indicating that the oil-in-water drilling fluid system has a strong inhibitory effect and efficient anti-collapse, well hole stability improved significantly.

After field application shows in Table 10, low density oil-in-water drilling fluid was optimized, prevention and treatment technology complexities of the construction process in shallow horizontal wells have strong adaptability, and achieved good results. The average net drilling utilization from 
$35.82 \% \nearrow 54.67 \%$, and increase of 52.6\%, significantly shortening the period of the horizontal well drilling.

Table 10 Test wells and non-test wells complexities fact table

\begin{tabular}{|c|c|c|c|c|c|}
\hline No & Well number & $\begin{array}{c}\text { Well depth } \\
\mathrm{m}\end{array}$ & $\begin{array}{c}\text { Pure drilling } \\
\text { efficiency } \\
\%\end{array}$ & $\begin{array}{c}\text { Drilling period } \\
\mathrm{d}\end{array}$ & Remark \\
\hline 1 & Xinsha $2 \mathrm{H}$ & 3232 & 38.40 & 110.49 & Non-test well \\
\hline 2 & Xinsha $311 \mathrm{H}$ & 3010 & 33.24 & 139 & Non-test well \\
\hline 3 & Xinsha 21-1H & 2940 & 52.15 & 75.42 & Test well \\
\hline 4 & Xinsha 23-1H & 3240 & 57.02 & 91.02 & Test well \\
\hline 5 & Xinsha 21-3H & 2942 & 54.74 & 53.81 & Test well \\
\hline
\end{tabular}

\section{Conclusions}

Single emulsifier can't emulsified crude oil well, can’t form stable oil-in-water emulsion system, while the use of complex ways to emulsify the effect of the original to be significantly more, including OP-10 + SP-80 ratio of 3: 2 complex was the best method.

The OP-10+SP-80 complex emulsifier system incorporated into conventional drilling fluid to form an oil-in-water drilling fluid has a good compatibility, it has high temperature stability, cake sticking coefficient was $0.0930 \sim 0.1014$, extreme pressure lubrication coefficient was 0.1885 0.2255, viscosity coefficient was $0.0262 \sim 0.0437$, below the horizontal drilling design requirements and can meet the needs of horizontal drilling wells.

Three wells test in field show, oil-in-water drilling fluid system has good rheological and lubricating properties, the average single well hole enlargement rate was $12.23 \%$, representing a decrease was $16.75 \%$, the average net drilling utilization from $35.82 \%$ up to $54.67 \%$, an increase of $52.6 \%$, shortening the period of the horizontal well drilling significantly.

\section{References}

[1] Tongtai, Xu etc, Horizontal well drilling and completion fluids [M], Petroleum Industry Press, 1999,12.

[2] Jinduo, Wang etc. The research and application of low oil-water ratio of oil-in-water drilling fluid system [J], Nature gas industry, 2008,28(7).

[3] Jun Chen etc. Experimental study of horizontal well carrying rocks in annular [J], Petroleum University Journal, 1992,16(4).

[4] Hao Chen etc. The problem analysis and countermeasure of drilling fluid carrying rock in great inclination and extended reach wells [J]. Shenli Oilfield Staff University Journal, 2009,23(3).

[5] Gaobo, Zhang etc. High temperature and low-density oil-in-water drilling fluids used in the Wengu 2 well. Drilling and completion fluids [J], 2002,19(3).

[6] Haige, Wang Xishen, Liu. The mechanism research of drilling fluid carrying rock in horizontal wells, Drilling and producing technology [J], 1996,19(2).

[7] Xuxin, Wan. Thoughts on optimization of horizontal well drilling fluid, Oil drilling technology [J], 1999,27(2).

[8] Yaxi, Chen. Application and technology status of horizontal drilling in abroad, Drilling and producing technology [J], 2001,24(5). 